\title{
Striking Visualization of Diffuse Congenital Nesidioblastosis on Ga-68 DOTATATE PET/CT
}

\author{
Diffüz Konjenital Nesidioblastosisin Ga-68 DOTATATE PET/BT'de Çarpıcı Olarak \\ Görüntülenmesi
}

\author{
(D) Fevziye Canbaz'1, (1) Murat Aydın², (1) Bilge Can Meydan³, (D) Meltem Ceyhan Bilgici4, (1) Ender Arıtürk \\ I Ondokuz Mayıs University Hospital, Department of Nuclear Medicine, Samsun, Turkey \\ 2Ondokuz Mayıs University Hospital, Department of Pediatric Endocrinology, Samsun, Turkey \\ ${ }^{3}$ Ondokuz Mayıs University Hospital, Department of Pathology, Samsun, Turkey \\ ${ }^{4}$ Ondokuz Mayıs University Hospital, Department of Pediatric Radiology, Samsun, Turkey \\ 5 Ondokuz Mayıs University Hospital, Department of Pediatric Surgery, Samsun, Turkey
}

\begin{abstract}
"Nesidioblastosis", later renamed as "persistent hyperinsulinemic hypoglycemia of infancy" presents as either focal or diffuse neo-differentiation of pancreatic Langerhans islet cells from the ductal epithelium. Differentiation of focal disease from diffuse involvement is crucial for optimal disease management. The current methods used to differentiate the two forms pre-operatively are invasive techniques. The definite role of imaging modalities to differentiate diffuse versus focal form has not yet been proven. Herein, we report a 15 day-old infant having diffuse nesidioblastosis, successfully demonstrated by Ga-68 DOTATATE positron emission tomography/computed tomography imaging that was histopathologically confirmed.
\end{abstract}

Keywords: Nesidioblastosis, hyperinsulinemic hypoglycemia, differential diagnosis, Ga-68 DOTATATE PET/CT

\section{Öz}

Pankreasın Langerhans ada hücrelerinin duktus epitelinden yeniden farklllaşması olan "nesidioblastosis", yeni adlandırımasıyla "yenidoğanın inatçı hiperinsülinemik hipoglisemisi", fokal ya da diffüz olarak iki şekilde görülebilir. Fokal formun diffüz olandan ayırt edilmesi hastalığın doğru yönetimi için son derece önemlidir. Bu iki formun cerrahi öncesi ayrımında kullanılan güncel metodlar invaziftir. Görüntülemenin diffüz formu fokal olandan ayırt etmedeki rolü tam olarak ortaya konamamıştır. Burada, Ga-68 DOTATATE pozitron emisyon tomografi/bilgisayarlı tomografi görüntüleme ile başarılı bir şekilde gösterilen ve histopatolojik olarak da doğrulanan diffüz nesidioblastosis hastası 15 günlük bir infant olgusunu sunduk.

Anahtar kelimeler: Nesidioblastosis, hiperinsülinemik hipoglisemi, ayıııı tanı, Ga-68 DOTATATE PET/BT

Address for Correspondence: Fevziye Canbaz MD, Ondokuz Mayıs University Hospital, Department of Nuclear Medicine, Samsun, Turkey Phone: +90 3623121919 - 2483 E-mail: fcanbazt@gmail.com ORCID ID: orcid.org/0000-0002-7759-0788

Received: 22.09.2018 Accepted: 04.11.2018

${ }^{\circ}$ Copyright 2019 by Turkish Society of Nuclear Medicine

Molecular Imaging and Radionuclide Therapy published by Galenos Yayınevi. 


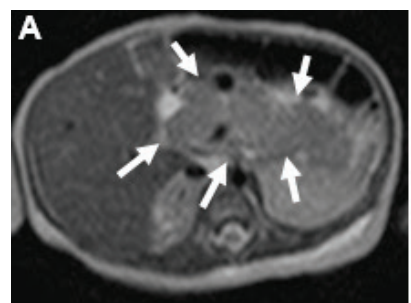

C

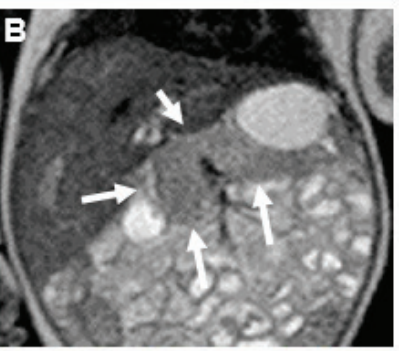

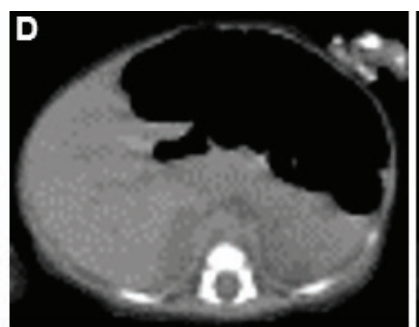
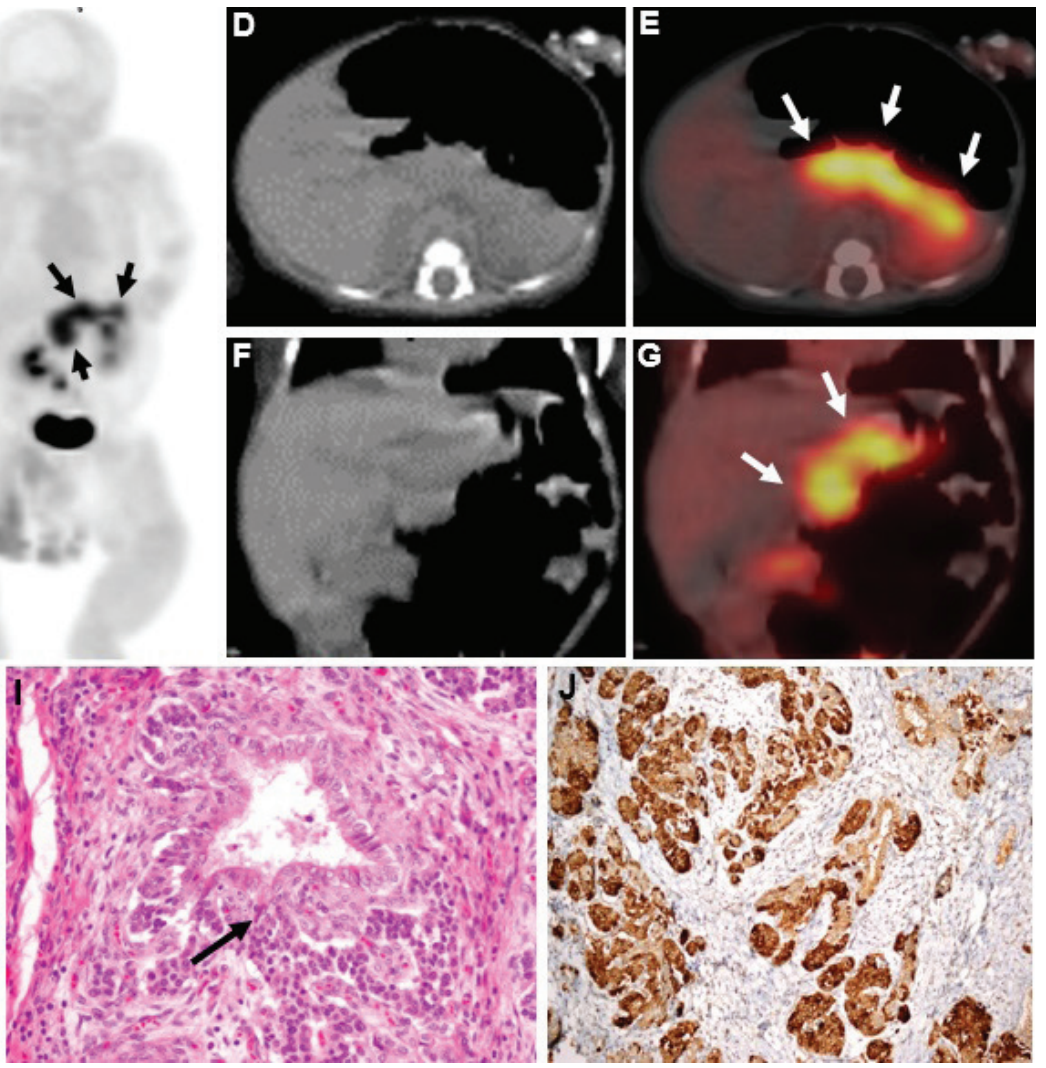

Figure 1. A 15-day-old infant presented with hyperinsulinemic hypoglycemia suffering from hypotonia, apnea and poor feeding. On physical examination, the abdomen was distended. The laboratory investigations revealed hypoglycemia (12 mg/dL, normal range: $70-110 \mathrm{mg} / \mathrm{dL}$ ) and hyperinsulinemia with serum insulin levels of $55 \mathrm{IU} / \mathrm{mL}$ (normal range: 2,42-13 IU $/ \mathrm{mL}$ ). The baby was administered intravenous glucose infusion up to $20 \mathrm{mg} / \mathrm{kg} / \mathrm{min}$ and oral feeding was supported with glucose to maintain euglycemic state. After intravenous diazoxide (15 mg/ $/ \mathrm{kg} /$ day) and octreotide therapy (30$45 \mathrm{mcg} / \mathrm{kg} / \mathrm{day}$ ), no sufficient response could be obtained. Axial (A) and coronal (B) T2-weighted magnetic resonance images demonstrated diffuse enlargement of the pancreas with normal parenchymal signal without any focal lesion. Ga-68 DOTATATE positron emission tomography/computed tomography (PET/CT) imaging [maximum intensity projection anterior (C), axial CT (D), fused PET/CT (E), coronal CT (F) and fused PET/CT (G)] showed diffusely increased tracer uptake (SUV ${ }_{\max }: 4,84 ; 3,99$ and 3,99 for head, corpus and tail of the pancreas, respectively) in the entire enlarged pancreas (arrows) (with physiological radiotracer distribution throughout the rest of the body) suggesting a diffuse variant of nesidioblastosis. Due to the persistent hyperinsulinemic hypoglycemia and considering the findings in the Ga-68 DOTATATE PET/CT somatostatin receptor imaging, the patient underwent near total pancreatectomy. Histopathologic findings confirmed the diagnosis of diffuse nesidioblastosis, demonstrating diffuse enlargement of pancreatic lobules composed of solid endocrine cell clusters without a tumor. The disarray of lobular architecture with diffuse and irregular hyperplasia of endocrine cells (H: H\&E, x100), the continuity between the duct epithelium and endocrine cells (the ductulo-insular complex, arrow) (I: H\&E, x200) and immunohistochemistry with chromogranin A staining endocrine cells (J: x200) are demonstrated. Congenital hyperinsulinism is the most common cause of persistent hypoglycemia in infancy, existing in two forms of either focal or a diffuse adenomatous hyperplasia of insulin secretion in the pancreas. The pre-operative differentiation of these two conditions is crucial for disease management $(1,2)$. Focal type can be treated by selective surgical resection in contrast to the diffuse form which requires near total pancreatectomy when resistant to medical treatment (3). No clinical or biological features are typical in determining disease type in affected infants. The current methods used for pre-operative differentiation are invasive techniques and do not always provide differential diagnosis $(4,5,6)$. The definite role of imaging modalities to differentiate diffuse versus focal form has not yet been proven. F-18-fluoro-dihydroxyphenylalanine PET scan has been used in case of hyperinsulinemia with a reported accuracy of $96 \%$ in diagnosing focal or diffuse disease, and of $100 \%$ in localizing the focal lesion $(3,7)$. To the best of our knowledge, only few case reports have been published regarding the role of somatostatin receptor imaging to distinguish focal disease from diffuse involvement, where Ga-68 DOTATATE PET scan had been applied successfully in one case and Ga-68 DOTATOC PET scan has been reported to have limited success in another report (1,8). The presented case is evident with an enlarged pancreas showing diffuse increased Ga-68 DOTATATE uptake and indicates somatostatin receptor imaging as a valuable option to guide the type of pancreatectomy in patients with persistent hyperinsulinemic hypoglycemia 


\section{Ethics}

Informed Consent: Consent form was filled out by all participants.

Peer-review: Externally and internally peer-reviewed.

\section{Authorship Contributions}

Surgical and Medical Practices: E.A., H.M.A., Concept: F.C., Design: F.C., Data Collection or Processing: F.C., Analysis or Interpretation: F.C., B.C.M., M.C.B., Literature Search: F.C., Writing: F.C.

Conflict of Interest: No conflict of interest was declared by the authors.

Financial Disclosure: The authors declared that this study received no financial support.

\section{References}

1. Dutta S, Venkataseshan S, Bal C, Rao KL, Gupta K, Bhattacharya A, Narang A. Novel use of somatostatin receptor scintigraphy in localization of focal congenital hyperinsulinism: Promising but fallible. J Pediatr Endocrinol Metab 2009;22:965-969.
2. de Lonlay-Debeney P, Poggi-Travert F, Fournet JC, Sempoux C, Dionisi Vici C, Brunelle F, Touati G, Rahier J, Junien C, Nihoul-Fékété C, Robert JJ, Saudubray JM. Clinical Features of 52 Neonates with Hyperinsulinism. N Engl J Med 1999;340:1169-1175.

3. Ribeiro MJ, De Lonlay P, Delzescaux T, Boddaert N, Jaubert F, Bourgeois S, Dollé F, Nihoul-Fékété C, Syrota A, Brunelle F. Characterization of hyperinsulinism in infancy assessed with PET and 18F-fluoro-L-DOPA. J Nucl Med 2005;46:560-566.

4. Brunelle F, Negre V, Barth MO, Fekete CN, Czernichow P, Saudubray JM, Kuntz F, Tach T, Lallemand D. Pancreatic venous samplings in infants and children with primary hyperinsulinism. Pediatr Radiol 1989;19:100-103.

5. Dubois J, Brunelle F, Touati G, Sebag G, Nuttin C, Thach T, Nikoul-Fekete C, Rahier J, Saudubray JM. Hyperinsulinism in children: Diagnostic value of pancreatic venous sampling correlated with clinical, pathological and surgical outcome in 25 cases. Pediatr Radiol 1995;25:512-516.

6. Rahier J, Guiot Y, Sempoux C. Persistent hyperinsulinaemic hypoglycaemia of infancy: a heterogeneous syndrome unrelated to nesidioblastosis. Arch Dis Child Fetal Neonatal Ed 2000;82:108-112.

7. Hardy OT, Hernandez-Pampaloni M, Saffer JR, Suchi M, Ruchelli E, Zhuang H, Ganguly A, Freifelder R, Adzick NS, Alavi A, Stanley CA. Diagnosis and Localization of Focal Congenital Hyperinsulinism by 18F-Fluorodopa PET Scan. J Pediatr 2007;150:140-145.

8. Arun S, Rai Mittal B, Shukla J, Bhattacharya A, Kumar P. Diffuse nesidioblastosis diagnosed on a Ga-68 DOTATATE positron emission tomography/computerized tomography. Indian J Nucl Med 2013;28:163164. 